\title{
BACTERIA AS A BIOLOGICAL ADMIXTURE IN CONCRETE
}

\author{
Likhit M.L ${ }^{1}$, Safdar Hussain ${ }^{2}$, Mahammad Asgar Ali ${ }^{3}$, Mahammad Thohir ${ }^{4}$, Mohammed Tayseer \\ ${ }^{I}$ Assistant Professor, Department of Civil Engineering, SCEM - Mangalore, Karnataka, India \\ ${ }^{2}$ Student, Department of Civil Engineering, SCEM - Mangalore, Karnataka, India \\ ${ }^{3}$ Student, Department of Civil Engineering, SCEM - Mangalore, Karnataka, India \\ ${ }^{4}$ Student, Department of Civil Engineering, SCEM - Mangalore, Karnataka, India \\ ${ }^{5}$ Student, Department of Civil Engineering, SCEM - Mangalore, Karnataka, India
}

\begin{abstract}
The main objective of the present study deals with the execution of the concrete by the microbiologically prompted unique growth/filler. One such thought has prompted the advancement of an extremely special concrete known as Bacterial Concrete where microscopic organisms is incited in the mortars and concrete to heal up the issues with various bacterium proposed at various bacterial concrete. Here a study was made by utilizing the microscopic organisms "Escherichia coli". Calcite arrangement by Escherichia coli is a model research facility bacterium, which can create calcite precipitates on suitable media supplemented with a Calcium source.Concrete cubes with and without addition of bacteria are studied and it is observed that there is an improvement in the compressive strength for the cubes with the addition of bacteria. Concrete cylinders with and without addition of bacteria was considered and it is observed that there is an improvement in the Split tensile strength for the cylinders with the addition of bacteria.
\end{abstract}

Keywords: Escherichia Coli, Compressive Strength, Split Tensile Strength.

\section{INTRODUCTION}

Concrete is a homogenous mixture of cement, fine aggregate, coarse aggregate and water. Concrete has a high load bearing capacity in compression, yet the material is weak in tension. Hence, to take up these tension, steel reinforcement bars are embedded in concrete of any structural element. When the concrete cracks under tension, the steel bars take up these loads. The concrete also acts as a barrier which protects the steel bars from the environment attack and prevents corrosion. Here the entrance of water and other moisture particles take place and deterioration of the structure begins with the corrosion of the steel.For increasing the durability of the concrete structure, either the cracks that are framed must be repaired later on or in the configuration stage additional reinforcement must be put in the structure to guarantee that the crack width stay within a specific least utmost. This extra reinforcement may be only needed for durability reasons and not for structural capability. Particularly with current steel costs this additional steel is uneconomical. Durability is one such reason to avoid cracks or reduce crack widths. However, if a reliable technique could be developed which repairs cracks in concrete automatically, this would increase and ensure durability and functionality developed that repair cracks in concrete extremely and also the extra steel that is used to limit the widths of cracks could most likely be saved to a huge amount.

Crack widths in concrete ought to be restricted, mostly for durability reasons. In case, if crack widths are too wide, the cracks should be repaired or an extra reinforcement is required in the design. If a method could be developed for repairing cracks in concrete automatically, this would save a large amount of money, both on the expenses of injection fluids on cracks and also on the additional steel that is placed in structures only to prevent crack widths. A dependable self-healing technique for concrete would prompt another method for planning durable concrete structures, which is beneficial for national and global economy.

\section{MATERIALS}

\subsection{Cement}

Ordinary Portland cement of evaluation accessible in nearby market is utilized as a part of the study. The bond utilized has been tried for different properties and found to be adjusting to particulars of IS: 8112-1989.

\subsection{Coarse aggregate}

The aggregates of $20 \mathrm{~mm}$ and below size are general used. The particular gravity of the coarse aggregates of totals of 2.6-2.8 is utilized. The physical attributes are tried according to IS 383:1970 procurements.

\subsection{Fine Aggregate}

The sand which is accessible provincially and is all around passing through $4.75 \mathrm{~mm}$ sieve is utilized as fine aggregate, affirming according to IS $383: 1970$ procurements. The examinations of the fine and coarse totals are affirmed to IS: 10262-2009. 


\subsection{Water}

Water utilized for blending and curing is crisp convenient water, insisting according to IS: $456-2000$.

\subsection{Bacteria}

A thermophilic, anaerobic microorganism isolated from the hot spring of Bakreshwar, India, belonging to the Shewanella species [2] was used in this study. This ironreducing microorganism was cultured anaerobically in a modified medium ( $\mathrm{pH} 7.5$ ) before adding to the cementsand mortar mixture. E. coli microorganisms grown in standard Luria Broth (LB) medium having $\mathrm{pH}$ of 7.2 were used to study their effect on mortar.

\section{METHODOLOGY}

The methodology for producing a self-healing bacterial concrete involves the following steps:

\subsection{Selection and Cultivation of Bacteria}

Pure cultures are maintained on nutrient agar slants and on nutrient agar plates. It forms irregular dry white colonies on nutrient agar plate. Whenever required, few colonies of the pure culture is added into nutrient broth of $25 \mathrm{ml}$ in $100 \mathrm{ml}$ conical flask. The growth conditions are maintained at $37^{\circ} \mathrm{C}$ temperature and placed in $125 \mathrm{rpm}$ orbital shaker. The growth medium used with the composition of nutrient agar is given below

Table 1: Quantity of growth medium extraction

\begin{tabular}{|c|c|}
\hline Nutrients & Amount \\
\hline Beef extract & $1.0 \mathrm{~g}$ \\
\hline Yeast extract & $2.0 \mathrm{~g}$ \\
\hline Peptone & $5.0 \mathrm{~g}$ \\
\hline Nacl & $5.0 \mathrm{~g}$ \\
\hline Agar & $15.0 \mathrm{~g}$ \\
\hline Distilled water & $1.01 \mathrm{~g}$ \\
\hline
\end{tabular}

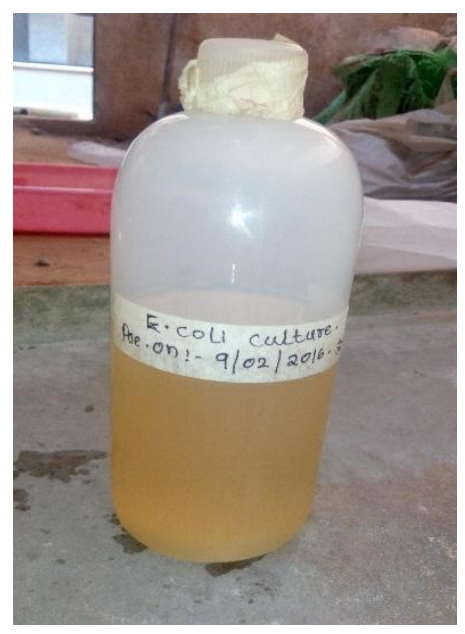

\subsection{Preparation of Test Specimens}

Bacterial concrete are casted by using ordinary Portland cement mixed with bacterial concentration $10^{6} \mathrm{cells} / \mathrm{ml}$ of water. Conventional concrete samples are also casted in parallel for comparing results with bacterial concrete. The specimens are cured under tap water at room temperature and tested at 7 and 28 days.

\subsection{Testing Procedure}

After the obliged time of curing, the samples are expelled from the curing tank and tested for compressive quality. The compressive quality of the samples at 7 days and 28 days is determined. The reported results are the normal of three trials.

\section{RESULTS AND DISCUSSION}

The primary goal of this examination is to contemplate the impact of expansion of the microorganism on the compressive quality of concrete. The results of the compressive quality at 7 days and 28 days for control specimens without micro-organism and for bond with microorganisms of suitable cell concentration of e.coli ( 105,106 and 107 cells for each $\mathrm{ml}$ of mixing water) is given underneath.

\begin{tabular}{|l|l|l|l|l|}
\hline \multicolumn{5}{|c|}{ Compressive strength $\left(\mathbf{N} / \mathbf{m m}^{2}\right)$} \\
\hline SI. No & $\begin{array}{l}\text { Curing } \\
\text { period } \\
\end{array}$ & $\begin{array}{l}\text { Normal } \\
\text { (days) }\end{array}$ & $\begin{array}{l}\text { concrete } \\
\left(\mathbf{N} / \mathbf{m m}^{2}\right)\end{array}$ & $\begin{array}{l}\text { Bacterial Concrete } \\
\left(\mathbf{N} / \mathbf{m m}^{2}\right)\end{array}$ \\
\cline { 4 - 5 } & $\mathbf{4 0 \%}$ & $\mathbf{6 0 \%}$ \\
\hline 1 & 7 & 20.1433 & 18.5166 & 18.07 \\
\hline 2 & 28 & 29.85 & 27.4 & 28.75 \\
\hline
\end{tabular}

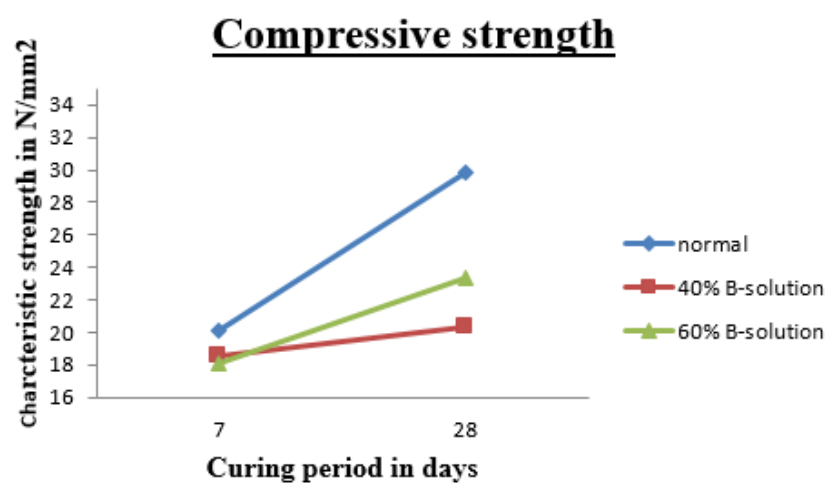

The test results revealed $8 \%$ and $3.6 \%$ decrease in Bacterial Concentrations at 28 days curing when compared to conventional concrete. The slump achieved Compressive Strength of concrete for $40 \%$ and $60 \%$ was $125 \mathrm{~mm}$ for $40 \%$ bacterial concrete and $135 \mathrm{~mm}$ for $60 \%$ bacterial concrete. This indicates that as the concentration of bacterial solution increases, workability also increases. 


\begin{tabular}{|c|c|c|c|c|}
\hline \multicolumn{5}{|c|}{ Split tensile strength $\left(\mathrm{N} / \mathrm{mm}^{2}\right)$} \\
\hline \multirow[t]{2}{*}{ Sl. No } & \multirow{2}{*}{$\begin{array}{l}\text { Curing } \\
\text { period } \\
\text { (days) }\end{array}$} & \multirow{2}{*}{$\begin{array}{l}\text { Normal } \\
\text { concrete } \\
\left(\mathrm{N} / \mathrm{mm}^{2}\right)\end{array}$} & \multicolumn{2}{|c|}{$\begin{array}{l}\text { Bacterial Concrete } \\
\left(\mathrm{N} / \mathrm{mm}^{2}\right)\end{array}$} \\
\hline & & & $40 \%$ & $60 \%$ \\
\hline 1 & 7 & 1.6503 & 1.273 & 1.4143 \\
\hline 2 & 28 & 2.3103 & 2.1216 & 2.263 \\
\hline
\end{tabular}

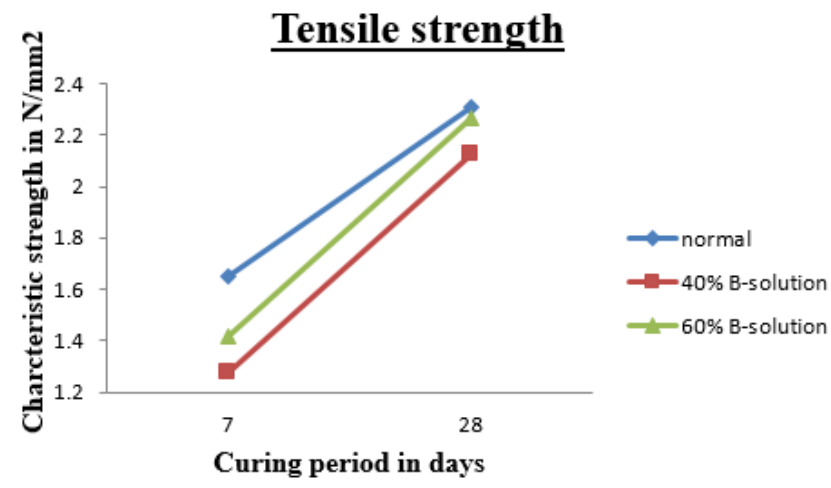

The results also revealed that there is $8 \%$ and $2 \%$ decrement in tensile strength of concrete for $40 \%$ and $60 \%$ Bacterial Concentrations at 28 days curing when compared to conventional concrete

\section{CONCLUSIONS}

It is concluded that the bacterial concrete will higher life span when compared to that of conventional concrete because calcite precipitate crystals impermeable the concrete specimen and resists the harmful solutions entering the concrete specimen there by reducing the deleterious effect which they may cause. However, there is no much improvement in strength of mortar with the addition of $\mathrm{E}$. coli. This concrete can be used to prevent cracks and hence saving the structure from corrosion of steel.

\section{ACKNOWLEDGEMENT}

The financial assistance to this experimental study received from Karnataka State Council for Science and Technology (KSCST), Bangalore, India is gratefully acknowledged. We would also acknowledge the help rendered by Mr Likhit m.l., Assistant Professor, Department of civil engineering, SCEM Mangalore.

\section{REFERENCES}

[1] P.K. Mehta, Advancement in concrete technology, Journal of Concrete

International (1999) 69- 75.

[2] D. Ghosh, B. Bal, V.K. Kashyap, S. Pal, Molecular phylogenetic exploration of bacterial division in a Bakreshwar (India) hot spring and culture of Shewanellarelated thermophiles, Journal of Applied and Environmental Microbiology 69 (7) (2003) 4332- 4336.

[3] Ramakrishnan, V., Bang, S.S., Srinivasan Neelamegam., and Ramesh, K.P., "Durability of Cement Mortar Made With Different Concentrations of Bacteria", Proceedings of 25th International Conference of Cement Microscopy, Richmond, Virginia, April 2003.

[4] S. Sunil Pratap Reddy, M.V. Seshagiri Raob, P. Aparnac and Ch. Sasikalac. (2010). "Performance of standard grade bacterial concrete." Asian journal of civil engineering (building and housing) | vol. 11, no. 1 (2010), pages 43-55.

[5] P. Ghosha, S. Mandala, B.D. Chattopadhyayb, S. Palc (2005), "Use of microorganism to improve the strength of cement mortar", cement and concrete research, 35, 19801983.

[6] IS 383: specification for coarse and fine aggregates from natural sources for concrete, Bureau of Indian Standard, New Delhi, 1970.

[7] IS-8112 (2013) "Specification for 43 grade ordinary Portland".

[8] IS- 10262:2009, “Concrete Mix Proportioning Guidelines", Bureau of Indian Standards, New Delhi.

\section{BIOGRAPHIES}

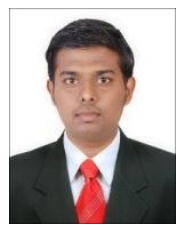

LIKHIT M L was born in Mysore, India, in 1990. He received the B.E. degree in Civil engineering from NMAMIT, Nitte India, in 2012, and the M.Tech. degree in Structual engineering from the Manipal Institute of Technology (MIT) Manipal, India, in 2014

respectively.

In 2015, he joined the Department of Civil Engineering, Sahaydri college of Engineering and Management as an Assistant Professor. Since January 2015, he has been with the Department of Civil Engineering. His current research interests include Prestressed concrete strucutres, concrete technology and advances in new trends in concrete technology, high rise structural design \& analysis and offshore structural analysis.

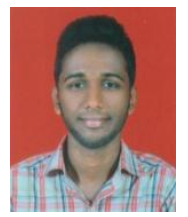

SAFDAR HUSSAIN was born in Mangalore, India, in 1994. He is currently pursuing B.E. degree in Civil engineering from Sahyadri college of engineering and management, Mangalore, India

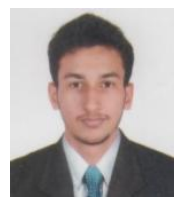

MAHAMMAD ASGAR ALI was born in Mangalore, India, in 1995. He is currently pursuing B.E. degree in Civil engineering from Sahyadri college of engineering and management, Mangalore, India

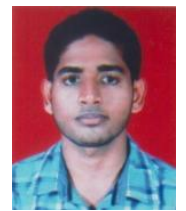

MAHAMMAD THOHIR was born in Mangalore, India, in 1994. He is currently pursuing B.E. degree in Civil engineering from Sahyadri college of engineering and management, Mangalore, India

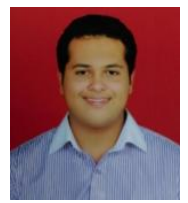

MOHAMMED TAYSEER was born in Mangalore, India, in 1994. He is currently pursuing B.E. degree in Civil engineering from Sahyadri College of engineering and management, Mangalore, India 